\title{
An appraisal of carbon footprint of milk from commercial grass-based dairy farms in Ireland according to a certified life cycle assessment methodology
}

\author{
Donal O'Brien • Padraig Brennan • James Humphreys • \\ Eimear Ruane • Laurence Shalloo
}

Received: 3 February 2014 / Accepted: 11 May 2014 / Published online: 14 June 2014

(C) The Author(s) 2014. This article is published with open access at Springerlink.com

\begin{abstract}
Purpose Life cycle assessment (LCA) studies of carbon footprint $(\mathrm{CF})$ of milk from grass-based farms are usually limited to small numbers of farms $(<30)$ and rarely certified to international standards, e.g. British Standards Institute publicly available specification 2050 (PAS 2050). The goals of this study were to quantify CF of milk from a large sample of grass-based farms using an accredited PAS 2050 method and to assess the relationships between farm characteristics and CF of milk.

Materials and methods Data was collected annually using onfarm surveys, milk processor records and national livestock databases for 171 grass-based Irish dairy farms with information successfully obtained electronically from 124 farms and fed into a cradle to farm-gate LCA model. Greenhouse gas (GHG) emissions were estimated with the LCA model in $\mathrm{CO}_{2}$ equivalents $\left(\mathrm{CO}_{2}\right.$-eq) and allocated economically between dairy farm products, except exported crops. Carbon footprint of milk was estimated by expressing GHG emissions attributed to milk per kilogram of fat and protein-corrected milk (FPCM). The Carbon Trust tested the LCA model for nonconformities with PAS 2050. PAS 2050 certification was achieved when non-conformities were fixed or where the effect of all unresolved non-conformities on CF of milk was $< \pm 5 \%$.

Results and discussion The combined effect of LCA model non-conformities with PAS 2050 on CF of milk was $<1 \%$.
\end{abstract}

Responsible editor: Matthias Finkbeiner

D. O’Brien $(\bowtie) \cdot J$. Humphreys $\cdot$ E. Ruane $\cdot$ L. Shalloo Livestock Systems Research Department, Animal \& Grassland Research and Innovation Centre, Teagasc, Moorepark, Fermoy, County Cork, Ireland

e-mail: donal.o'brien@teagasc.ie

P. Brennan

Bord Bia, Clanwilliam Court, Lower Mount Street, Dublin 2, Ireland
Consequently, PAS 2050 accreditation was granted. The mean certified CF of milk from grass-based farms was $1.11 \mathrm{~kg}$ of $\mathrm{CO}_{2}$-eq $/ \mathrm{kg}$ of $\mathrm{FPCM}$, but varied from 0.87 to $1.72 \mathrm{~kg}$ of $\mathrm{CO}_{2^{-}}$ eq $/ \mathrm{kg}$ of FPCM. Although some farm attributes had stronger relationships with $\mathrm{CF}$ of milk than the others, no attribute accounted for the majority of variation between farms. However, CF of milk could be reasonably predicted using $\mathrm{N}$ efficiency, the length of the grazing season, milk yield/cow and annual replacement rate $\left(R^{2}=0.75\right)$. Management changes can be applied simultaneously to improve each of these traits. Thus, grass-based farmers can potentially significantly reduce CF of milk.

Conclusions The certification of an LCA model to PAS 2050 standards for grass-based dairy farms provides a verifiable approach to quantify CF of milk at a farm or national level. The application of the certified model highlighted a wide range between the $\mathrm{CF}$ of milk of commercial farms. However, differences between farms' CF of milk were explained by variation in various aspects of farm performance. This implies that improving farm efficiency can mitigate CF of milk.

Keywords Carbon footprint - Certification · Dairy · Grass · Greenhouse gas · Milk

\section{Introduction}

Grass-based dairy production is a key agricultural industry in some developed nations, particularly Ireland and New Zealand. The dairy sector internationally, however, is also an important source of greenhouse gas (GHG) emissions, responsible for approximately $3 \%$ of global emissions (Opio et al. 2013), $10 \%$ of Ireland's emissions and up to $20 \%$ of New Zealand emissions (Beukes et al. 2010; Deighton et al. 2010). Climate change caused by GHG emissions has become an important political issue. This has led to growing awareness 
amongst consumers of the potential adverse effects of climate change, which is expected to increase the demand for food products that generate low GHG emissions (Roy et al. 2009). In light of this anticipated demand, major retailers (e.g. Tesco and Wal-Mart) have already put in place sustainability programs to monitor emissions associated with the production of their food products. Therefore, quantifying GHG emissions from all milk-producing nations is becoming a pre-requisite, but especially for countries like Ireland, which export the majority (85\%) of their dairy products (CSO 2013).

Simple simulation models of complex biological and technical processes are used to quantify GHG emissions from milk given that direct measurement of agricultural GHG sources (e.g. soils) is difficult and cost prohibitive. The preferred approach to simulate GHG emissions from milk production is the life cycle assessment (LCA). Ideally, LCA should be applied to quantify emissions from all life cycle phases of milk, such as farming, processing, consumption and waste treatment. The methodology, though, is generally applied to the cradle to farm-gate stage of dairy production and, thus, only simulates emissions associated with milk prior to the sale of the product from the farm (Yan et al. 2011). Firstly, this is because of the variation between farming systems, and secondly, most GHG emissions from milk are emitted during the farm stage. For instance, LCA studies of milk to the retail stage report the cradle to farm-gate stage causes $78-95 \%$ of GHG emissions from milk (Defra 2007; Gerber et al. 2010).

Usually studies apply a cradle to farm-gate LCA approach to compare the GHG emission intensity or carbon footprint (CF) of milk ( $\mathrm{kg}$ of GHG/unit of milk) from contrasting dairy farms (O'Brien et al. 2010; Flysjö et al. 2011) or use the approach to assess GHG mitigation strategies (Rotz et al. 2010). The majority of previous research though has been carried out on a limited number $(<20-30)$ of farms (generally not randomly chosen) or based on a single-point modelled national average farm, because significant resources are required to conduct an LCA study of dairy farms (Thomassen et al. 2009). However, researchers are increasingly overcoming this resource challenge, in part through improvements in mobile computer technology (e.g. Thoma et al. 2013). Thus, this implies that there is an increasing scope to complete LCA studies of CF of milk with a large sample of farms $(>100)$.

The major advantage of performing LCA on a large number of dairy farms is that it provides an insight into the variation between $\mathrm{CF}$ of milk from commercial farms, which is generally not possible through national average estimates or small-scale studies. In addition, differences between the CF of milk from dairy farms may be related to variation in farm performance (e.g. milk yield/ha), which can facilitate the development of management practices or mitigation strategies to reduce CF of milk (Thomassen et al. 2009). However, apart from DairyCo (2012), previous large-scale European cradle to farm-gate LCA studies of CF of milk have only considered farms where cows do not graze or graze for a short period, usually no longer than 5 months. Thus, strategies suggested to reduce $\mathrm{CF}$ of milk from such studies will not be applicable to grass-based farms where cows graze for an extended period (e.g. 9-10 months; O'Brien et al. 2012).

Although several studies have used LCA to quantify CF of milk from grass-based dairy farms, the application of the methodology varies between studies (Yan et al. 2011). To try to overcome this methodology challenge, LCA was applied according to the British Standards Institute (BSI 2011) publicly available specification 2050:2011 (PAS 2050) LCA standard for GHG emissions. In addition, to comply with PAS 2050 certification requirements, an accredited third party (Carbon Trust) assessed all LCA procedures. The goal of this study was to quantify $\mathrm{CF}$ of milk from a significant group $(>100)$ of grass-based dairy farms using an LCA method independently accredited to comply with PAS 2050 standards. Additionally, we aimed to determine the factors that caused variation amongst farms' carbon footprints of milk. The study was limited to Ireland, but is also relevant to developed nations where extended grazing of dairy cattle is practiced, given that the application of a certified LCA method to assess emissions from a large sample of grass-based dairy farms is rare.

\section{Materials and methods}

\subsection{Data collection}

A random sample of 171 commercial Irish dairy farms was audited between November 2011 and December 2012. The farms sampled were located in the northeast, east, southeast, south and southwest of the country. The farms assessed were therefore a subset of the country's dairy farms and, thus, not representative of the population's CF of milk. The Carbon Trust provided guidance on randomly selecting dairy farms for the region. All data was collected electronically using annual on-farm surveys, electronic feeds of dairy processor milk data and livestock data (DAFM 2011; ICBF 2012).

The Department of Agriculture, Food and the Marine (DAFM) animal identification and movement (AIM) system was used to source bovine data from dairy farms. The AIM system records all births, movements and disposal of farm animals on a daily basis. It is highly reliable and used to meet EU requirements on traceability for bovines (DAFM 2011). Trained auditors carried out farm surveys that corresponded to a 1-year period (fiscal year). Three to $4 \mathrm{hrs}$ of data collection was sufficient to survey a farm, provided source documents, for instance accounting books, were available. Farm auditors collected information on key parameters, for instance, the area of the dairy enterprise, grazing management, concentrate feed, manure management and use of fertiliser, fuel and contractors. 
In addition, auditors collected farm livestock inventory data, which was cross-checked with national livestock databases (DAFM 2011; ICBF 2012).

Electronic data collected was fed into a farm database to operate an LCA model to calculate the CF of milk from dairy farms. The process described to collect data was externally verified by the Carbon Trust. The Carbon Trust audited farms by cross-checking electronic data collected with farm invoices, milk supply records, auditor measurements and farm livestock records. During this validation procedure, 45 farms were excluded from the analysis because of inadequate or unreliable data (e.g. inconsistency between farmer records of livestock numbers and AIM records). Two more farms were omitted from the evaluation because they had or began to cease producing milk during the period of the study. In total, 124 dairy farms were analysed.

The majority $(70 \%)$ of farms analysed were grass-based spring calving systems where the aim was to minimize costs through maximizing the proportion of grazed grass in the diet (Kennedy et al. 2005). To achieve this goal, farmers synchronized calving with the onset of grass growth in early or midspring and cows remained at pasture from calving until late autumn or early winter. Pasture was usually offered to cows through a rotational grazing system, where cows were offered sections of pasture for 1-2 days or until a specific grazing height was reached (e.g. 4-5 cm) and then moved to a new section. When grass growth exceeded herd feed demand, surplus grass was harvested as grass silage, hay or both and fed to cows indoors from early winter to early spring. Cows were supplemented with purchased concentrate feeds, when grass growth was insufficient to meet herd feed requirements.

Spring calving grass-based dairy systems are the dominant method of producing milk in Ireland (Evans et al. 2004). Thus, the supply pattern of milk is highly seasonal, greatest in May and lowest in January. There is a requirement for some milk to be produced out of season for the fluid milk market and specialty-type products. In order to incentivize farmers to supply milk during the winter period, dairy processors offer farmers a winter contract with a milk price bonus to cover the extra costs of production (Fitzgerald et al. 2004). To meet this requirement, a minority of farms analysed calved cows in autumn or throughout the year. Thus, these farms offered milking cows concentrate feed over the winter and, in addition to grass silage, fed maize silage, whole crop silage or both. Farms that milked cows throughout the winter, however, also aim to graze cows for an extended period (6-8 months) to minimize costs, particularly in late autumn and early spring (Fitzgerald et al. 2004).

\subsection{Greenhouse gas simulation}

A cradle to farm-gate attributional LCA model developed by O'Brien et al. (2010) was used to simulate annual GHG emissions from dairy farms. Thus, all sources of GHG emissions associated with dairy production until milk leaves the farm were simulated, including off-farm GHG sources such as fertiliser production (Fig. 1). The model calculated GHG emissions by combining information from the farm database, mentioned previously, with literature emission algorithms. However, the LCA model procedures and literature emission factors were adapted based on farm data availability and recommendations of the Carbon Trust. In addition, fluorinated gases (F-gases) from refrigerant loss were added to the model as a source of GHG emissions and estimated based on farm service records of cooling equipment.

The main on-farm sources of GHG emissions quantified by the LCA model are summarized in Table 1. Enteric methane $\left(\mathrm{CH}_{4}\right)$ emissions were estimated by firstly computing animal feed intakes. To ensure animal feed intakes were realistic, they were calculated to fulfil net energy requirements for milk production, maintenance, pregnancy and body weight change (Jarrige 1989). Where possible, information directly acquired on animal and feed variables were used to validate feed intakes. However, this was not possible for all variables, for instance energy values of forages. Thus, data from literature sources were also used (O’Mara 1996, 2006). Enteric $\mathrm{CH}_{4}$ emissions were estimated as a function of intake, using a fixed factor of $6.5 \%$ of gross energy intake (GEI) when cattle grazed grass (Duffy et al. 2011b). However, when the diet comprised of only silage and concentrate, a regression equation from Yan et al. (2000) was used.

Methane emissions from manure were estimated according to the Intergovernmental Panel on Climate Change IPCC (2006) guidelines as a proportion of the maximum $\mathrm{CH}_{4}$ potential $\left(B_{\mathrm{o}}\right)$ of manure volatile solids (VS). Based on O'Mara (2006), manure VS excretion was calculated by multiplying animal organic matter (OM) intake by the indigestible OM component of the diet. The quantity of manure VS requiring storage was computed based on the number of days animals spent housed. The $B_{\mathrm{o}}$ of manure VS for dairy cattle was based on Duffy et al. (2011b). The proportion of the $B_{\mathrm{o}}$ that was emitted from manure VS was computed using specific $\mathrm{CH}_{4}$ conversion factors for different manure storage systems, but for manure deposited on pasture, a default factor (1\%) was used (IPCC 2006). The $\mathrm{CH}_{4}$ conversion factors for manure storage systems were selected assuming an annual average ambient temperature of $10^{\circ} \mathrm{C}$ for Ireland (Met 2013).

Emissions of nitrous oxide $\left(\mathrm{N}_{2} \mathrm{O}\right)$ from manure were derived after calculating $\mathrm{N}$ excretion, which was estimated as the difference between total $\mathrm{N}$ intake and $\mathrm{N}$ output in meat and milk. Direct $\mathrm{N}_{2} \mathrm{O}$ emissions from manure storage were estimated using manure storage-specific emission factors. After subtraction of $\mathrm{N}$ losses during housing and storage, $\mathrm{N}_{2} \mathrm{O}$ emissions from manure spreading were estimated as $1 \%$ of $\mathrm{N}$ applied (IPCC 2006). In addition, this factor was used to estimate $\mathrm{N}_{2} \mathrm{O}$ emissions from synthetic fertiliser spreading, 
Fig. 1 An illustration of the major sources of on- and off-farm greenhouse gas emissions, carbon dioxide $\left(\mathrm{CO}_{2}\right)$, methane $\left(\mathrm{CH}_{4}\right)$, nitrous oxide $\left(\mathrm{N}_{2} \mathrm{O}\right)$ and fluorinated gases (F-gases), quantified using a cradle to farmgate life cycle assessment model

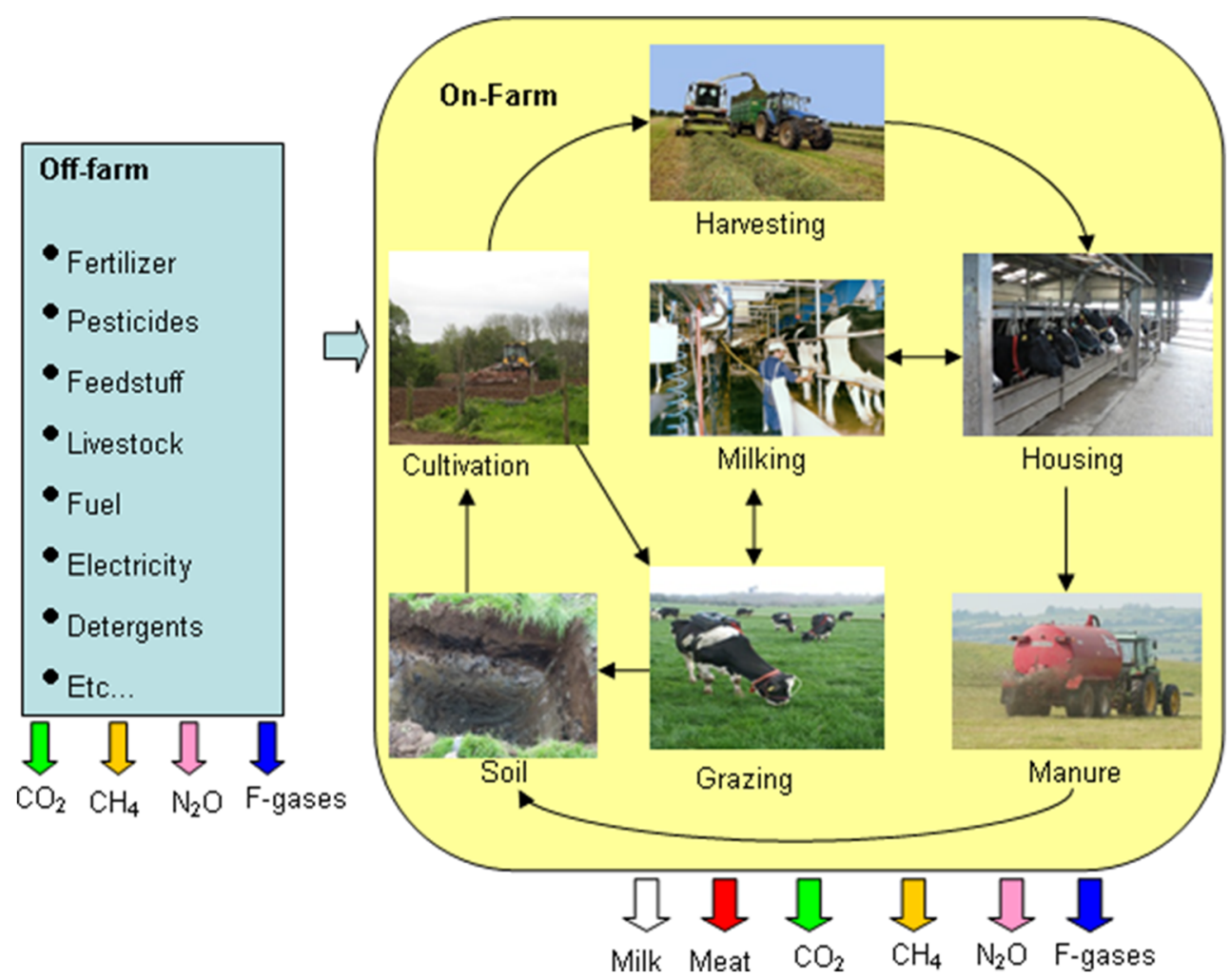

neutral with respect to GHG emissions given that the IPCC (2006) assume all C absorbed by animals, crops and manure to be quickly released back to the atmosphere through respiration, burning and decomposition. Agricultural soils also have the potential to emit or sequester $\mathrm{CO}_{2}$ (Rotz et al. 2010). However, to comply with PAS 2050, C sequestration was not included for permanent pasture. This was because the standard follows the IPCC (2006) recommendation that soil's ability to store or lose $\mathrm{C}$ reaches equilibrium after a fixed period (20 years). Thus, land use change emissions were also restricted to this period and estimated as $6.7-7.0 \mathrm{t} \mathrm{CO}_{2} /$ ha per annum when permanent on-farm grassland was converted to cropland (Carbon Trust 2013).

Data acquired on external farm inputs (e.g. diesel and pesticides) were used primarily with emission factors (Table 2 ) from the Carbon Trust (2013) to estimate off-farm GHG emissions. For electricity generation and some other sources though, it was more appropriate to use emission algorithms from national literature sources. When emissions from an external farm input could not be estimated via the Carbon Trust or national literature, Ecoinvent (2010) was used. The production of specific imported feeds, for instance Malaysian palm kernel, was estimated to cause land use change emissions by computing the average land use change emissions for that crop in that country (Carbon Trust 2013). Directly attributing land use change emissions to a crop conforms to the method used by the Food and Agriculture Organization (FAO) to estimate GHG emissions from milk (Opio et al. 2013). 
Table 1 Key emission factors applied in a cradle to farm-gate life cycle assessment model to quantify on-farm greenhouse gas (GHG) emissions, ammonia emissions and nitrate loss

\begin{tabular}{|c|c|c|c|}
\hline Emission and source & Emission factor & Unit & References \\
\hline \multicolumn{4}{|l|}{ Carbon dioxide $\left(\mathrm{CO}_{2}\right)$} \\
\hline Lime & $0.12 \times$ lime application & $\mathrm{kg} / \mathrm{kg}$ lime & IPCC (2006) \\
\hline Urea & $0.20 \times$ urea application & $\mathrm{kg} / \mathrm{kg}$ urea & IPCC (2006) \\
\hline Diesel & $2.63 \times$ diesel use & $\mathrm{kg} / \mathrm{l}$ & IPCC (2006) \\
\hline Gasoline & $2.30 \times$ gasoline use & $\mathrm{kg} / \mathrm{l}$ & IPCC (2006) \\
\hline Kerosene & $2.52 \times$ kerosene use & $\mathrm{kg} / 1$ & IPCC (2006) \\
\hline Liquefied petroleum gas (LPG) & $1.49 \times$ LPG use & $\mathrm{kg} / 1$ & IPCC (2006) \\
\hline \multicolumn{4}{|l|}{ Methane $\left(\mathrm{CH}_{4}\right)$} \\
\hline \multicolumn{4}{|l|}{ Enteric fermentation } \\
\hline Dairy cow and heifer (housing) & $\mathrm{DEI} \times\left(0.096+0.035 \times S_{\mathrm{DMI}} / T_{\mathrm{DMI}}\right)-(2.298 \times \mathrm{FL}-1)$ & $\mathrm{MJ} /$ day & Yan et al. (2000) \\
\hline Dairy cow and heifer (grazing) & $0.065 \times \mathrm{GEI}$ & MJ/day & Duffy et al. (2011b) \\
\hline Manure storage and excretion on pasture & Manure VS excreted $\times 0.24 \times 0.67 \times \mathrm{MS}^{\mathrm{a}} \times \mathrm{MCF}^{\mathrm{b}}$ & $\mathrm{kg} /$ year & IPCC (2006); Met (2013) \\
\hline \multicolumn{4}{|l|}{ Nitrous oxide $\left(\mathrm{N}_{2} \mathrm{O}\right)$} \\
\hline Slurry storage & $0.005 \times$ slurry $\mathrm{N}$ stored & $\mathrm{kg} / \mathrm{kg} \mathrm{N}$ & IPCC (2006) \\
\hline Solid manure storage & $0.005 \times$ solid manure $\mathrm{N}$ stored & $\mathrm{kg} / \mathrm{kg} \mathrm{N}$ & IPCC (2006) \\
\hline Manure excreted on pasture & $0.02 \times \mathrm{N}$ excreted on pasture & $\mathrm{kg} / \mathrm{kg} \mathrm{N}$ & IPCC (2006) \\
\hline Synthetic N fertiliser & $0.01 \times \mathrm{N}$ fertiliser & $\mathrm{kg} / \mathrm{kg} \mathrm{N}$ & IPCC (2006) \\
\hline Manure application & $0.01 \times($ manure $\mathrm{N}$ applied $-\mathrm{N}$ storage loss $)$ & $\mathrm{kg} / \mathrm{kg} \mathrm{N}$ & IPCC (2006) \\
\hline Crop residues & $0.01 \times \mathrm{N}$ crop residues & $\mathrm{kg} / \mathrm{kg} \mathrm{N}$ & IPCC (2006) \\
\hline Nitrate leaching & $0.0075 \times \mathrm{N}$ leached & $\mathrm{kg} / \mathrm{kg} \mathrm{NO}_{3}{ }^{-} \mathrm{N}$ & IPCC (2006) \\
\hline Ammonia $\left(\mathrm{NH}_{3}\right)$ re-deposition & $0.01 \times$ sum of $\mathrm{NH}_{3}$ loss & $\mathrm{kg} / \mathrm{kg} \mathrm{NH}-\mathrm{N}$ & IPCC (2006) \\
\hline \multicolumn{4}{|l|}{ Ammonia $\left(\mathrm{NH}_{3}-\mathrm{N}\right)$} \\
\hline Housing & $11-38^{\mathrm{c}}$ & g/luuk per day & Duffy et al. (2011a) \\
\hline Slurry storage & $(2-4)^{\mathrm{d}} \times$ area slurry store & $\mathrm{g} / \mathrm{m}^{2}$ per day & Duffy et al. (2011a) \\
\hline Solid manure storage & $94 \times$ area solid manure store & $\mathrm{g} / \mathrm{m}^{2}$ per year & Duffy et al. (2011a) \\
\hline Slurry application & $(0.15-0.59)^{\mathrm{e}} \times \mathrm{TAN}$ in slurry spread & $\mathrm{kg} / \mathrm{kg}$ TAN & Duffy et al. (2011a) \\
\hline Solid manure application & $0.81 \times \mathrm{TAN}$ in solid manure spread & $\mathrm{kg} / \mathrm{kg}$ TAN & Duffy et al. (2011a) \\
\hline Grazing cattle & $0.2 \times \mathrm{N}$ excreted on pasture & g/luuk per day & Duffy et al. (2011a) \\
\hline Synthetic $\mathrm{N}$ fertiliser & $(0.08-0.23)^{\mathrm{f}} \times \mathrm{N}$ fertiliser applied & $\mathrm{kg} / \mathrm{kg} \mathrm{N}$ & Duffy et al. (2011a) \\
\hline \multicolumn{4}{|l|}{ Nitrate $\left(\mathrm{NO}_{3}{ }^{-}-\mathrm{N}\right)$} \\
\hline $\mathrm{N}$ leaching & $0.1 \times\left(\mathrm{N}\right.$ applied $-\mathrm{NH}_{3}$ loss $-\mathrm{N}_{2} \mathrm{O}$ loss $)$ & $\mathrm{kg} / \mathrm{kg} \mathrm{N}$ & Duffy et al. (2011b) \\
\hline
\end{tabular}

$D E I$ digestible energy intake, $S_{D M I}$ silage dry matter intake, $T_{D M I}$ total dry matter intake, $F L$ feeding levels above maintenance energy requirement, $G E I$ gross energy intake, $V S$ volatile solids, luuk UK livestock unit (equivalent to $500 \mathrm{~kg}$ body weight), TAN total ammoniacal nitrogen

${ }^{a} \mathrm{MS}=$ percentage of manure volatile solids managed in a specific storage system or percentage of manure excreted on pasture

${ }^{\mathrm{b}} \mathrm{MCF}=$ methane conversion factor for manure volatile solids managed in a particular storage system or excreted on pasture. The MCF values were 0.01 for manure excreted on pasture, 0.02 for solid manure system (dry matter $(\mathrm{DM})>20 \%$ ), 0.66 for lagoon system and 0.17 for slurry system without a surface crust or 0.11 with a surface crust

${ }^{\mathrm{c}}$ Dependent on the age of the animal

${ }^{\mathrm{d}}$ Dependent on manure storage facility

${ }^{\mathrm{e}}$ Dependent on DM of slurry and season of application

${ }^{\mathrm{f}}$ Dependent on fertiliser compound

2.3 Quantification and accreditation of CF of milk from dairy farms

On- and off-farm GHG emissions were converted to $\mathrm{CO}_{2}$ equivalent $\left(\mathrm{CO}_{2}\right.$-eq) emissions using the IPCC (2007) guidelines' global warming potential (GWP) factors, which have been revised (IPCC 2013) and summed to compute dairy farms' annual $\mathrm{CO}_{2}$-eq emissions. The GWP factors for key GHG emissions were 1 for $\mathrm{CO}_{2}, 25$ for $\mathrm{CH}_{4}$ and 298 for $\mathrm{N}_{2} \mathrm{O}$, assuming a 100 -year time horizon. The $\mathrm{CF}$ of milk from dairy farming was estimated by firstly allocating GHG emissions between farm outputs, milk, crops, manure and meat from 
Table 2 Key emission factors used in a cradle to farm-gate life cycle assessment model for quantification of off-farm greenhouse gas emissions in kilograms of $\mathrm{CO}_{2}$ equivalent

\begin{tabular}{|c|c|c|}
\hline Item & Emission factor & Reference \\
\hline Electricity, kWh & 0.60 & Howley et al. (2011) \\
\hline Diesel, 1 & 0.41 & Ecoinvent (2010) \\
\hline Gasoline, 1 & 0.57 & Ecoinvent (2010) \\
\hline Kerosene, 1 & 0.39 & Ecoinvent (2010) \\
\hline Liquefied petroleum gas, 1 & 0.30 & Ecoinvent (2010) \\
\hline Ammonium nitrate, $\mathrm{kg} \mathrm{N}$ & 7.11 & Carbon Trust (2013) \\
\hline Urea, $\mathrm{kg} \mathrm{N}$ & 3.07 & Ecoinvent (2010) \\
\hline Lime, $\mathrm{kg}$ & 0.15 & Carbon Trust (2013) \\
\hline $\mathrm{P}$ fertiliser, $\mathrm{kg} \mathrm{P}_{2} \mathrm{O}_{5}$ & 1.86 & Carbon Trust (2013) \\
\hline $\mathrm{K}$ fertiliser, $\mathrm{kg} \mathrm{K}_{2} \mathrm{O}$ & 1.77 & Carbon Trust (2013) \\
\hline Refrigerant, $\mathrm{kg}$ & $11.00-393.00$ & Little (2002) \\
\hline Detergent, $\mathrm{kg}$ active ingredient & $0.11-1.03$ & Ecoinvent (2010) \\
\hline Pesticide, $\mathrm{kg}$ active ingredient & 7.37 & Carbon Trust (2013) \\
\hline Barley, kg dry matter (DM) & 0.35 & Carbon Trust (2013) \\
\hline Corn grain, $\mathrm{kg} \mathrm{DM}$ & 0.45 & Carbon Trust (2013) \\
\hline Citrus pulp, kg DM & 0.06 & Carbon Trust (2013) \\
\hline Corn gluten, kg DM & 0.34 & Carbon Trust (2013) \\
\hline Molasses, kg DM & 0.15 & Carbon Trust (2013) \\
\hline Rapeseed meal, kg DM & 0.40 & Carbon Trust (2013) \\
\hline South America soybean meal, $\mathrm{kg}$ DM & 11.65 & Carbon Trust (2013) \\
\hline USA soybean meal, $\mathrm{kg}$ DM & 0.32 & Carbon Trust (2013) \\
\hline South America soybean hulls, kg DM & 0.28 & $\begin{array}{l}\text { Ecoinvent (2010) } \\
\text { Carbon Trust (2013) }\end{array}$ \\
\hline USA soybean hulls, $\mathrm{kg}$ DM & 0.01 & $\begin{array}{l}\text { Ecoinvent (2010) } \\
\text { Carbon Trust (2013) }\end{array}$ \\
\hline Compound concentrate, $16 \%$ crude protein $^{\mathrm{a}}(\mathrm{CP}), \mathrm{kg} \mathrm{DM}$ & 0.34 & $\begin{array}{l}\text { Ecoinvent (2010) } \\
\text { Carbon Trust (2013) }\end{array}$ \\
\hline Compound concentrate, $20 \% \mathrm{CP}^{\mathrm{b}}, \mathrm{kg} \mathrm{DM}$ & 1.98 & $\begin{array}{l}\text { Ecoinvent (2010) } \\
\text { Carbon Trust (2013) }\end{array}$ \\
\hline Compound concentrate, $32 \% \mathrm{CP}^{\mathrm{c}}, \mathrm{kg} \mathrm{DM}$ & 3.37 & $\begin{array}{l}\text { Ecoinvent (2010) } \\
\text { Carbon Trust (2013) }\end{array}$ \\
\hline
\end{tabular}

${ }^{\text {a }}$ Concentrate formulation on a DM basis: USA soy hulls $18 \%$, USA dried distillers grains $17 \%$, USA citrus pulp $17 \%$, USA corn gluten feed $8 \%$, French rapeseed meal $8 \%$, German corn grain $6 \%$, Cuban molasses $5 \%$, Irish barley $5 \%$, Malaysian palm kernel meal $4 \%$, Irish wheat feed $4 \%$, vegetable oil $3 \%$, Irish lime $3 \%$, minerals and vitamins $2 \%$

${ }^{\mathrm{b}}$ Concentrate formulation on a DM basis: Irish wheat feed $17 \%$, USA soy hulls $16 \%$, French rapeseed meal $15 \%$, Brazilian soybean meal $14 \%$, German corn grain $7 \%$, Cuban molasses $6 \%$, Malaysian palm kernel meal $6 \%$, USA dried distillers grains $4 \%$, USA citrus pulp $4 \%$, French sunflower meal $4 \%$, Irish lime $3 \%$, vegetable oil $2 \%$, minerals and vitamins $2 \%$

${ }^{\mathrm{c}}$ Concentrate formulation on a DM basis: Brazilian soybean meal $26 \%$, French rapeseed meal $24 \%$, USA dried distillers grains $12 \%$, Malaysian palm kernel meal $8 \%$, USA soy hulls $7 \%$, Cuban molasses $6 \%$, USA corn gluten feed $5 \%$, French sunflower meal $4 \%$, Irish lime $3 \%$, vegetable oil $3 \%$, minerals and vitamins $2 \%$

culled cows and surplus calves. Where possible, PAS 2050 recommendations to avoid allocation of GHG emissions between products were applied. However, this was only achieved for exported crops by constraining the LCA model to quantify emissions from crops grown for dairy cattle.

When allocation was required, GHG emissions were allocated between dairy farm products based on their economic value. The economic method of allocation was used instead of alternative methods, e.g. the physical allocation approach recommended by the IDF (2010), because economic allocation is preferred by PAS 2050 when allocation cannot be avoided. The economic value of milk and meat was estimated using 5-year average prices from 2007 to 2011 (CSO 2013). Cattle manure exported from dairy farms had no economic value. Thus, GHG emissions were allocated to cattle manure based on the site of storage and application. Emissions from the transport of exported manure were attributed to the importer. Greenhouse gas emissions attributed to milk were 
expressed per kilogram of fat and protein-corrected milk (FPCM) to quantify the CF of milk from dairy farms. An algorithm from the International Dairy Federation (IDF 2010) was used to estimate FPCM as $4 \%$ fat and $3.3 \%$ true protein.

The LCA model estimate of CF of milk was tested by the Carbon Trust to certify compliance with PAS 2050. Research data from Teagasc (2011) on poor, average and high performing grass-based Irish dairy farms were initially used to evaluate the model. Subsequently, research data from Olmos et al. (2009) was used to test the model's ability to estimate CF of milk from a high input farm where cows did not graze. The LCA model was also tested with data from commercial farms. This was achieved by randomly selecting 12 grass-based farms from the study sample.

To achieve accreditation, non-conformities identified by the Carbon Trust between the LCA model and PAS 2050 were addressed. Non-conformities that had a non-material impact on the $\mathrm{CF}$ of milk were either justified through research data or changed based on advice of the Carbon Trust. PAS 2050 certification was granted when all non-conformities were addressed or where the effect of all unresolved non-material non-conformities on the $\mathrm{CF}$ of milk was $< \pm 5 \%$. To determine if the LCA model CF result was within the $< \pm 5 \%$ threshold, all changes recommended by the Carbon Trust were applied to any model non-conformity with PAS 2050.

\subsection{Statistical analyses}

The Statistical Analysis Systems (SAS) Institute software package (SAS 2008) was used to evaluate relationships between farm characteristics (e.g. herd size) and CF of milk. The strength of the relationship between CF of milk and individual farm characteristics was measured using the Pearson correlation where the data was normally distributed and the Spearman rho correlation for non-normal data. Correlations were also performed amongst farm characteristics, where a farm variable was correlated to $\mathrm{CF}$ of milk. Least squares regression analysis was used to evaluate the associations between individual farm variables and $\mathrm{CF}$ of milk. The equality of the variances of residuals of regression models was checked for normality visually and the Shapiro-Wilk test was used $(P<0.05)$. The significance of regression coefficients was assessed using the $t$ statistic.

Non-linear terms were added to regression models based on a visual assessment of the distribution of the residuals. The stepwise multiple regression procedure of SAS (2008) was used to determine whether the addition of non-linear terms made a significant contribution $(P<0.05)$ to a regression equation. The procedure was also used to develop predictive models by assessing the relationship between the CF of milk and all farm characteristics listed in Tables 3 and 4. Variance inflation factors and condition indices were applied in SAS (2008) to check for multicollinearity within multiple regression models. Regression coefficients with variance inflation factors $>10$ were omitted.

\section{Results}

\subsection{General farm characteristics}

The weighted mean, standard deviation (SD), coefficient of variation $(\mathrm{CV})$ and range for various farm characteristics of 124 dairy farms are shown in Table 3. On average, dairy farms were 51 ha in size, stocked at 2.1 livestock units (LU)/ha and produced $489 \mathrm{t}$ of FPCM. The mean herd size was 91 cows and the replacement rate averaged $19 \%(\mathrm{SD}=8 \%)$ across farms. Cows spent the majority of the year at pasture (mean of 245 grazing days, $\mathrm{SD}=23$ ). Thus, their diet was mainly composed of grazed grass (mean $63 \%$; $\mathrm{SD}=7 \%$ ). Concentrate input averaged $643 \mathrm{~kg} \mathrm{DM} / \mathrm{cow}(\mathrm{SD}=310)$ across farms, and the mean quantity of forage purchased was $118 \mathrm{~kg} \mathrm{DM} / \mathrm{cow}$ $(\mathrm{SD}=202)$. On-farm $\mathrm{N}$ fertiliser application averaged $172 \mathrm{~kg} \mathrm{~N} / \mathrm{ha}(\mathrm{SD}=54)$ and the mean farm-gate $\mathrm{N}$ surplus $(\mathrm{N}$ imports-N exports) was $150 \mathrm{~kg} \mathrm{~N} / \mathrm{ha}(\mathrm{SD}=53)$. On-farm electricity consumption averaged $47 \mathrm{kWh}$ of electricity/t of FPCM $(\mathrm{SD}=18)$ and fuel use was $97 \mathrm{l}$ of fuel/ha $(\mathrm{SD}=15)$.

\subsection{Certified CF of milk from Irish dairy farms}

All non-conformities identified between the LCA model and PAS 2050 during evaluation of the CF of milk from dairy farms were addressed. Generally, non-conformities were resolved by applying changes recommended by the Carbon Trust, but for some non-conformities considered nonmaterial (e.g. simulation of manure excretion by cattle), no revisions were undertaken. Overall, the cumulative effect of non-material non-conformities was $<1 \%$. Thus, $\mathrm{CF}$ of milk estimated by the LCA model was accredited to comply with PAS 2050.

On average, $90 \%$ of dairy farms' GHG emissions were allocated to milk production. The mean certified CF of milk to the farm-gate, weighted by farm milk production, was $1.11 \mathrm{~kg}$ of $\mathrm{CO}_{2}$-eq $/ \mathrm{kg}$ of FPCM. The SD was within $\pm 0.13 \mathrm{~kg}$ of $\mathrm{CO}_{2}$ eq of the weighted mean. Figure 2 shows across the 124 dairy farms that there was significant variability between farms' CF of milk, ranging from 0.87 to $1.72 \mathrm{~kg}$ of $\mathrm{CO}_{2}$-eq $/ \mathrm{kg}$ of FPCM. On average, $\mathrm{CF}$ of milk mainly consisted of $\mathrm{CH}_{4}(47 \%)$ and $\mathrm{N}_{2} \mathrm{O}(34 \%)$ emissions, followed by emissions of $\mathrm{CO}_{2}(19 \%)$ and F-gases $(<0.5 \%)$. Approximately, $80 \%$ of the $\mathrm{CF}$ of milk to the farm-gate was caused by GHG emissions generated directly on-farm.

The largest individual on-farm contributor to $\mathrm{CF}$ of milk was $\mathrm{CH}_{4}$ from enteric fermentation (44\%), which averaged $113 \mathrm{~kg} \mathrm{CH}_{4} /$ cow. Nitrous oxide from manure excreted by 
Table 3 Weighted means, standard deviations (SD), coefficients of variations (CV), minimum, maximum and lower and upper 10 percentiles of key farm characteristics of 124 Irish dairy farms

\begin{tabular}{|c|c|c|c|c|c|c|c|}
\hline Farm characteristic & Mean & SD & CV $(\%)$ & Min & Lower $10 \%$ & Upper $10 \%$ & $\operatorname{Max}$ \\
\hline Farm size, ha & 51 & 27 & 52 & 18 & 30 & 75 & 245 \\
\hline Stocking rate, LU/ha & 2.10 & 0.46 & 22 & 1.30 & 1.50 & 2.60 & 2.93 \\
\hline Cows, $n$ & 91 & 55 & 60 & 29 & 44 & 149 & 468 \\
\hline Annual FPCM yield/cow & 5,380 & 834 & 16 & 3,163 & 4,433 & 6,483 & 8,071 \\
\hline Annual FPCM yield/ha & 9,494 & 2,534 & 27 & 4,529 & 6,435 & 12,832 & 15,085 \\
\hline Fat, \% & 3.89 & 0.17 & 4 & 3.54 & 3.71 & 4.13 & 4.31 \\
\hline Protein, $\%$ & 3.38 & 0.10 & 3 & 3.10 & 3.26 & 3.51 & 3.73 \\
\hline Lactose, $\%$ & 4.70 & 0.05 & 1 & 4.48 & 4.64 & 4.76 & 4.84 \\
\hline Replacement rate, $\%$ & 19 & 8 & 43 & 7 & 9 & 28 & 36 \\
\hline Grazing season, days & 245 & 23 & 9 & 184 & 214 & 274 & 280 \\
\hline Concentrate, $\mathrm{kg} \mathrm{DM} / \mathrm{cow}$ & 643 & 310 & 48 & 224 & 310 & 1,062 & 1,552 \\
\hline Purchased forage, $\mathrm{kg} \mathrm{DM} / \mathrm{cow}$ & 118 & 202 & 171 & 0 & 0 & 337 & 1,197 \\
\hline Total feed, kg DM/cow & 5,630 & 549 & 10 & 4,270 & 4,961 & 6,350 & 6,444 \\
\hline On-farm $\mathrm{N}$ fertiliser, $\mathrm{kg} / \mathrm{ha}$ & 172 & 54 & 32 & 95 & 112 & 255 & 307 \\
\hline Farm-gate $\mathrm{N}$ surplus ${ }^{\mathrm{a}}, \mathrm{kg} / \mathrm{ha}$ & 150 & 53 & 36 & 70 & 87 & 231 & 240 \\
\hline Farm $\mathrm{N}$ efficiency ${ }^{\mathrm{b}}, \%$ & 27 & 7 & 25 & 14 & 20 & 37 & 39 \\
\hline Electricity, $\mathrm{kWh} / \mathrm{cow}$ & 253 & 98 & 38 & 57 & 152 & 388 & 409 \\
\hline On-farm fuel, 1/ha & 97 & 15 & 15 & 41 & 78 & 116 & 121 \\
\hline
\end{tabular}

$L U$ livestock unit (equivalent to the average annual $\mathrm{N}$ excretion of an Irish dairy cow); FPCM fat and protein-corrected milk, where milk was standardised to $4 \%$ fat and $3.3 \%$ true protein per kilogram; DM dry matter

${ }^{\mathrm{a}} \mathrm{N}$ imports- $\mathrm{N}$ exports passing in or out through the farm-gate

${ }^{\mathrm{b}}$ Farm $\mathrm{N}$ exports/farm $\mathrm{N}$ imports

grazing cattle was the next largest on-farm contributor (17\%) to $\mathrm{CF}$ of milk, followed by $\mathrm{N}_{2} \mathrm{O}$ and $\mathrm{CO}_{2}$ emissions from fertiliser application $(8 \%), \mathrm{CH}_{4}$ and $\mathrm{N}_{2} \mathrm{O}$ emissions from manure storage and spreading $(6 \%)$ and $\mathrm{CO}_{2}$ emissions from fuel consumption and lime (5\%). The remainder of the CF of milk comprised of off-farm GHG emissions from fertiliser manufacture $(10 \%)$, concentrate production ( $7 \%$ ) and energy generation $(3 \%)$. The majority of GHG emissions from concentrate production were caused by $\mathrm{CO}_{2}$ emissions from land use change (57\%).

\subsection{Associations between farm characteristics and CF of milk}

Significant $(P<0.05)$ associations between farm characteristics and $\mathrm{CF}$ of milk were linear. Farm $\mathrm{N}$ efficiency had the strongest negative correlation with CF of milk $(r=-0.66$; Table 4), which regression analysis found decreased CF of milk by $13 \mathrm{~g}$ of $\mathrm{CO}_{2}$-eq (standard error $(\mathrm{se})=1$ ) for each $1 \%$ increase in $\mathrm{N}$ efficiency. Apart from total farm milk production, measures of milk yield were moderately negatively correlated to $\mathrm{CF}$ of milk, but the correlation was stronger when evaluated per hectare $(r=-0.55)$ rather than per cow $(r=$ -0.48 ). Milk yield/cow had a similar negative correlation with $\mathrm{CF}$ of milk as homegrown forage utilisation per hectare, but a slightly stronger correlation than the length of the grazing season $(r=-0.45)$. Moderate to weak negative correlations ( $r=-0.24$ to -0.32 ) occurred between CF of milk and milk fat content, milk protein content, total feed intake/cow and stocking rate.

Farm N surplus per hectare and purchased forage/cow were the only farm attributes positively correlated to $\mathrm{CF}$ of milk, but the correlations were weak ( $r=0.20$ to 0.28$)$. Annual replacement rate, farm size and herd size were not associated with CF of milk. However, stepwise multiple regression (Table 5) showed that $\mathrm{CF}$ of milk could be reasonably well explained $\left(R^{2}=0.75\right)$ by farm $\mathrm{N}$ efficiency, the length of the grazing season, milk yield/cow and annual replacement rate. Of these farm attributes, the procedure found that the majority of variation in CF of milk amongst farms was explained by farm $\mathrm{N}$ efficiency.

\section{Discussion}

The application of LCA according to PAS 2050 highlighted a significant variation in the $\mathrm{CF}$ of milk amongst grass-based dairy farms. The differences between CF of milk were mainly related to variation in aspects of farm performance and characteristics. Thus, this indicates that grass-based dairy 
Table 4 Correlations $(r)$ between various farm characteristics and carbon footprint (CF) of milk

\begin{tabular}{lll}
\hline Farm characteristic & CF of milk & $P$ value \\
\hline Farm size, ha & 0.07 & NS \\
Cows, $n$ & -0.04 & NS \\
Cows/ha & -0.33 & $* * *$ \\
Stocking rate, LU/ha & -0.32 & $* * *$ \\
Total farm milk production, t FPCM & -0.17 & NS \\
Annual FPCM yield/cow & -0.48 & $* * *$ \\
Annual FPCM yield/ha & -0.55 & $* * *$ \\
Fat, \% & -0.24 & $* *$ \\
Protein, \% & -0.31 & $* * *$ \\
Lactose, \% & -0.18 & NS \\
Replacement rate, \% & 0.03 & NS \\
Grazing season, days & -0.45 & $* * *$ \\
Concentrate, kg DM/cow & 0.15 & NS \\
Purchased forage, kg DM/cow & 0.20 & $*$ \\
Total feed, kg DM/cow & -0.24 & $* *$ \\
On-farm forage use, kg/ha & -0.48 & $* * *$ \\
On-farm N fertiliser, kg/ha & 0.09 & NS \\
Farm-gate N surplus, kg/ha & 0.28 & $* *$ \\
Farm N efficiency,$\%$ & -0.66 & $* * *$ \\
Electricity, kWh/cow & 0.10 & NS \\
On-farm fuel, l/ha & 0.06 & NS \\
\hline
\end{tabular}

Fat and protein-corrected milk standardised to $4 \%$ fat and $3.3 \%$ true protein per kilogram

$L U$ livestock unit (equivalent to the annual $\mathrm{N}$ excretion of an average Irish dairy cow), $D M$ dry matter, $N S$ not significant

$* P<0.05 ; * * P<0.01 ; * * * P<0.001$

${ }^{a} \mathrm{~N}$ imports- $\mathrm{N}$ exports passing in or out through the farm-gate

${ }^{\mathrm{b}}$ Farm $\mathrm{N}$ exports/farm $\mathrm{N}$ imports

producers can mitigate the $\mathrm{CF}$ of milk by adopting management practices that improve efficiency and performance. Furthermore, the study suggests that the goals of maintaining farm profitability and reducing CF of milk are not contradictory, given that previous studies of grass-based research farms report that improving farm productivity increases profit (Lovett et al. 2008; O’Brien et al. 2010). However, no single farm attribute accounted for the majority of variation between farms' CF of milk. Thus, the study implies, similar to Beukes et al. (2010), that a suite of farm practices are required to increase efficiency and thus reduce carbon footprint of milk.

\subsection{Comparisons with national and international studies}

Relative to previous single-point estimates of the national average CF of Irish milk (Casey and Holden 2005; Lovett et al. 2008; Teagasc 2011), our mean result for commercial dairy farms was lower by $7-16 \%$. This was primarily because we considered a subset of dairy farms that were on average

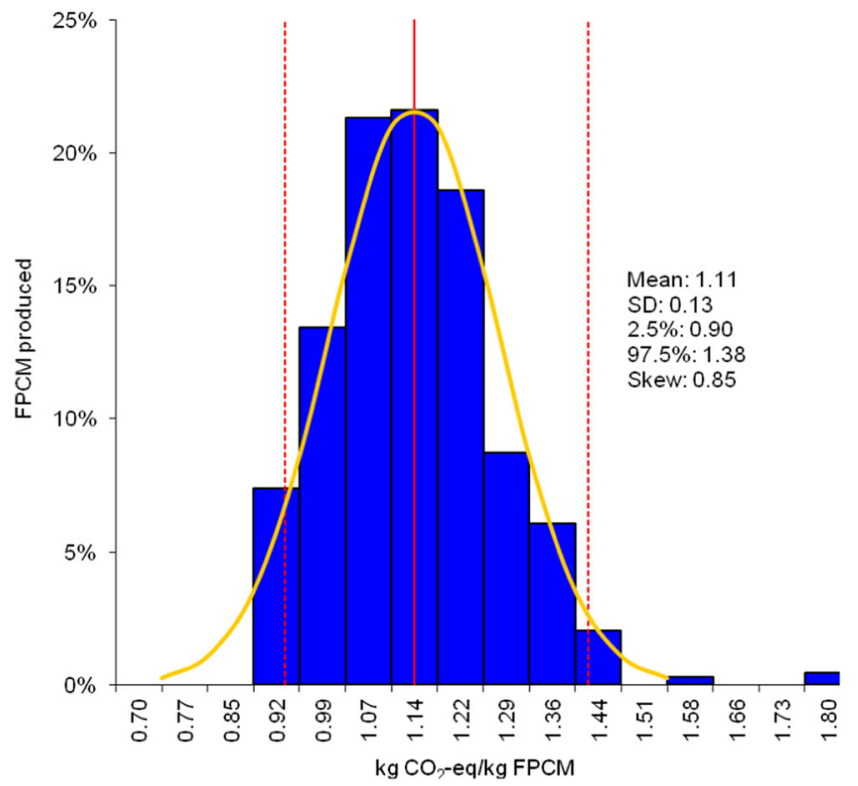

Fig. 2 Histogram and expected normal distribution (bell-shaped line) of carbon footprint of fat and protein-corrected milk (FPCM), weighted by farm FPCM production for 124 dairy farms in $\mathrm{CO}_{2}$ equivalent $\left(\mathrm{CO}_{2}\right.$-eq). The middle vertical solid line indicates the mean value and the dotted vertical lines to the left and right of the mean indicate the interval between the lower $2.5 \%$ and upper $97.5 \%$ of values. The mean carbon footprint of milk and standard deviation (SD) are also shown

moderately more productive (e.g. higher milk yield/ha) than the national average farm. For example, compared to the performance of the average Irish dairy farm for 2010 and 2011 (Teagasc 2011), the farms analysed produced more FPCM/cow $(5,380$ versus $5,058 \mathrm{~kg})$ and per hectare $(9,494$ versus $8,982 \mathrm{~kg}$ ) and fed approximately $276 \mathrm{~kg}$ DM less concentrate/cow. In addition, the mean period cows spent at pasture was longer than the national average, which Lovett et al. (2008) reported and the present results indicate to mitigate GHG emissions from grass-based dairy production. However, relative to a recent European estimate of the average CF of Irish milk by Leip et al. (2010), our results were

Table 5 Regression coefficients (b), associated standard errors (SE), significance of regression coefficient and coefficient of determination $\left(R^{2}\right)$ estimated in a stepwise multiple regression model of carbon footprint of milk

\begin{tabular}{lllll}
\hline Parameter & $b$ & SE & $P$ value & $R^{2}$ \\
\hline Intercept & 2.19 & 0.08 & $* * *$ & - \\
N efficiency ${ }^{\text {a }} \%$ & -0.98 & 0.10 & $* * *$ & 0.46 \\
Grazing season, days & $-2.16 \times 10^{-3}$ & $2.71 \times 10^{-4}$ & $* *$ & 0.61 \\
FPCM yield/cow & $-7.76 \times 10^{-5}$ & $9.87 \times 10^{-6}$ & $* *$ & 0.70 \\
Replacement rate, \% & $3.37 \times 10^{-3}$ & $9.43 \times 10^{-4}$ & $*$ & 0.75 \\
\hline
\end{tabular}

Fat and protein-corrected milk standardised to $4 \%$ fat and $3.3 \%$ true protein per kilogram

${ }^{*} P<0.05 ; * * P<0.01 ; * * * P<0.001$

${ }^{\text {a }}$ Farm $\mathrm{N}$ exports/farm $\mathrm{N}$ imports 
approximately $10 \%$ higher, despite the greater efficiency of the dairy farms we assessed. The anomaly, though, was simply due to different LCA modelling assumptions.

For instance, Leip et al. (2010) included carbon sequestration by permanent grassland, which PAS 2050 excludes based on the IPCC (2006) guidelines. Recent studies report that permanent grasslands are an important long-term carbon sink (Soussana et al. 2007, 2010). Adopting the same carbon sequestration assumptions in the present study as Leip et al. (2010) reduced the mean CF of milk to $0.95 \mathrm{~kg}$ of $\mathrm{CO}_{2}$-eq $/ \mathrm{kg}$ FPCM, which is $5 \%$ lower than the estimate of Leip et al. (2010) of the average CF of Irish milk. Thus, as more carbon sequestration data becomes available, PAS 2050 may need to be revised to include this sink. The large influence that alternative modelling choices (e.g. allocation methodologies) have on the CF of milk and meat is a well-documented LCA issue (Flysjö et al. 2011). Thus, until a harmonised LCA approach such as PAS 2050 is widely adopted internationally, direct comparisons between CF studies of milk are of limited value. Consequently, the FAO is leading a livestock environmental assessment and performance partnership (LEAP 2014) to develop global LCA guidelines for a wide array of environmental impacts from livestock. The draft LEAP guidelines generally adopt the same principles as PAS 2050, but are specific for animal supply chains.

Although methodological variations often partially explain differences between LCA studies, cautious comparisons can provide an indication of the validity of LCA results and are useful in understanding the potential to mitigate $\mathrm{CF}$ of milk. Our results were similar to pan-European and global LCA studies, which showed that grazing systems of developed nations have the lowest CF of milk (Leip et al. 2010; Hagemann et al. 2012; Opio et al. 2013). However, such studies generally only assess the national or regional average situation and do not assess the variation in CF of milk within a region. Several reports suggest that this variation is significant. For instance, DairyCo (2012) showed that even though the average CF of UK milk was in the lower range of literature estimates, substantial differences were found amongst 415 grazing and non-grazing dairy systems' CF of milk (0.83-2.81 kg of $\mathrm{CO}_{2}$-eq/l of fat corrected milk). A similar variability has also been reported for CF of Dutch milk (Thomassen et al. 2009) and USA milk (Thoma et al. 2013) where commercial non-grazing systems were predominately assessed and by an Australian evaluation of 140 grazing and non-grazing dairy systems (Dairy Australia 2012). In addition, the results of these studies show that farmers of developed nations can reduce $\mathrm{CF}$ of milk via management changes, e.g. DairyCo (2012) reported that reducing concentrate supplementation of cows decreased CF of milk of dairy farms. Thus, this indicates that global or European single-point estimates of national CF of milk may underestimate the scope to mitigate GHG emissions.
Generally, our analysis agreed with large-scale LCA studies (e.g. Thomassen et al. 2009; Dairy Australia 2012) regarding the range of farms' CF of milk and the main sources of dairy farms' GHG emissions (e.g. enteric $\mathrm{CH}_{4}$ ). However, unlike LCA studies of similar scale, the farms we considered were not nationally representative and, as discussed marginally, more productive than the national average dairy farm. Consequently, the variability amongst farms' CF of milk was lower than previous large-scale LCA studies (e.g. DairyCo 2012). There was, however, a significant variation amongst key sources of dairy farms' GHG emissions, particularly $\mathrm{N}_{2} \mathrm{O}$ emissions from manure and emissions associated with onfarm fertiliser use. The variability of these GHG sources was similar to previous reports by Dairy Australia (2012) and Thoma et al. (2013). Thus, these results suggest that there is potential to mitigate GHG emissions of grass-based dairy systems, which can be realised in part by adopting new technologies, but also via changes in farm management practices.

\subsection{Impact of farm efficiency and performance on CF of milk}

Similar to Casey and Holden (2005), Christie et al. (2011) and Yan et al. (2013b), numerous measures of farm efficiency and performance were correlated to CF of milk from grass-based farms. Congruous with Yan et al. (2013a), the farm attribute that had the strongest association with CF of milk was farm $\mathrm{N}$ efficiency (farm $\mathrm{N}$ imports/farm $\mathrm{N}$ exports). Key management practices that improve $\mathrm{N}$ efficiency of grass-based farms included adoption of white clover, greater utilisation of manure and better timing of manure and fertiliser application to grass growth. These practices reduced surplus $\mathrm{N}$ or the requirement for $\mathrm{N}$ fertiliser, which increased farm $\mathrm{N}$ efficiency. However, reducing $\mathrm{N}$ use on an area or animal basis rather than per unit of milk had little or no influence on CF of milk, which agrees with similar analysis by Olesen et al. (2006). Therefore, this may explain why several studies have generally not found or reported weak relationships between farm $\mathrm{N}$ use and $\mathrm{CF}$ of milk, given that most studies only assess farm N use per hectare (Dairy Australia 2012; DairyCo 2012).

Grass-based farms that were not efficient from an $\mathrm{N}$ perspective, however, did not necessarily have a high CF of milk. The main explanation for this was improving farm $\mathrm{N}$ efficiency primarily reduced emissions associated with $\mathrm{N}$ fertiliser, but had no effect on enteric $\mathrm{CH}_{4}$ emissions, which were the main components of farms' CF of milk. Therefore, farms that emitted lower enteric $\mathrm{CH}_{4}$ emissions/unit of milk than more $\mathrm{N}$ efficient farms could achieve a lower CF of milk. Increasing milk yield/cow and reducing the annual herd replacement rate were the primary farm attributes that mitigated enteric $\mathrm{CH}_{4}$ emissions. Improving these attributes increased feed conversion efficiency (total feed DM/kg of FPCM), which in agreement with Rotz et al. (2010) was the main determinant of 
enteric $\mathrm{CH}_{4}$ emissions/unit of milk. Increasing cow genetic merit via artificial insemination was the main management practice available to farmers to increase cow milk performance. Furthermore, the practice could also be used to improve cow fertility or health, which reduces the requirement for replacement heifers. However, this was achievable only using sires of a total genetic merit index, e.g. Irish economic breeding index (EBI), which are bred to increase cow performance, fertility and health.

Improving milk yield/cow also reduced $\mathrm{CF}$ of milk, but only caused minor reductions in $\mathrm{GHG}$ emissions from $\mathrm{N}$ inputs, e.g. fertiliser. In addition, similar to Ramsbottom et al. (2012), higher milk yield/cow was associated with greater concentrate feeding, which increased GHG emissions. Consequently, milk yield/cow was not as influential in determining CF of milk as farm $\mathrm{N}$ efficiency. Improving milk yield per hectare rather than per cow had less of an influence on feed conversion efficiency, but tended to cause a greater improvement in $\mathrm{N}$ efficiency. Furthermore, the measure increased homegrown forage utilisation per hectare, which in agreement with previous studies, reduced emissions from concentrate (Thomassen et al. 2009; O'Brien et al. 2010). Thus, improving milk yield per hectare had a slightly greater mitigating influence than increasing milk output/cow on $\mathrm{CF}$ of milk. Stocking rate was a key determinant of milk yield per hectare. However, stocking rate had little or no effect on feed conversion efficiency. Thus, this explained the lower influence milk yield per hectare had on feed conversion efficiency relative to milk yield/cow and the weak negative association between stocking rate and CF of milk.

Homegrown forage utilisation per hectare was primarily determined by stocking rate, but had a stronger association with CF of milk. This was because the farm attribute, unlike stocking rate, tended to be positively associated with the grazing season. Extending the grazing season shortened the winter housing period, which similar to Schils et al. (2005, 2007) reduced GHG emissions from on-farm fuel use, manure storage and spreading. In addition, the management practice increased grazed grass utilisation per hectare, which decreased GHG emissions from concentrate and, in contrast to the results of Schils et al. (2007), reduced enteric $\mathrm{CH}_{4}$ emissions. However, the main forage fed to cows indoors in the study of Schils et al. (2007) was maize silage, whereas in the present study, grass silage was mainly fed, which yields more enteric $\mathrm{CH}_{4}$ than grazed grass (Robertson and Waghorn 2002). Therefore, our results showed, unlike Schils et al. (2005, 2007), that extending the grazing season reduced CF of milk, but the negative association was only moderate. This was because the farm practice also increased $\mathrm{N}_{2} \mathrm{O}$ emissions from manure excreted on pasture by grazing cattle.

No single farm attribute analysed explained the majority of variation between the CF of milk from grass-based farms. As a result, similar to previous studies, improving farm measures in isolation had a minor mitigating effect on CF of milk (Lovett et al. 2008; Dairy Australia 2012; DairyCo 2012). Nevertheless, CF of milk from grass-based farms could be well predicted using just farm $\mathrm{N}$ efficiency, the length of the grazing season, milk yield/cow and the annual herd replacement rate. Thus, it may not be necessary to conduct detailed on-farm surveys to estimate CF of milk. However, to validate the prediction capabilities of these farm attributes, a new independent audit would need to be conducted.

As discussed, the farm attributes that predicted CF of milk were influenced by farm management practices, e.g. stocking rate, which varied to a similar or greater extent as GHG emissions between farms. Therefore, in order to reduce carbon footprint of milk, grass-based dairy farmers need to implement a suite of management practices to simultaneously improve farm $\mathrm{N}$ efficiency, the length of the grazing season, milk yield/ cow and the annual herd replacement rate. Farm management practices that positively influenced these key determinants of $\mathrm{CF}$ of milk and did not negatively interact were improving cow total genetic merit via artificial insemination, extending the length of the grazing season, reducing concentrate feeding, increasing stocking rate and reducing fertiliser $\mathrm{N}$ use per hectare by increasing the proportion of manure applied in spring. Furthermore, implementing these practices improves farm productivity. This increases the economic viability of grass-based farms (Lovett et al. 2008; Beukes et al. 2010; O'Brien et al. 2014) which is a key consideration when changing management practices. Therefore, this implies that grass-based dairy farmers can potentially significantly mitigate $\mathrm{CF}$ of milk and maintain farm profitability.

\section{Conclusions}

Independent certification of an LCA model according to PAS 2050 for a large group of grass-based dairy farms provides a verifiable approach to quantify $\mathrm{CF}$ of milk at a farm or national level. The application of the certified model in this study showed that the mean CF of milk from a subset of grassbased Irish farms was in the lower range of literature estimates. However, comparisons with previous LCA studies that were not certified to the PAS 2050 standard were affected by inconsistent modelling assumptions and choices. Therefore, this highlights the need for experts to use an internationally standardised LCA approach to estimate CF of milk, for instance PAS 2050 or IDF (2010) dairy LCA guidelines, which can be externally certified by an accredited third party, e.g. Carbon Trust.

As expected, differences between grass-based farms' CF of milk were primarily explained by variation in measures of farm performance, particularly farm $\mathrm{N}$ efficiency. Therefore, this suggests grass-based farmers can reduce $\mathrm{CF}$ of milk and 
maintain or increase farm profit by adopting management practices that increase efficiency, e.g. improving cow total genetic merit. However, no individual farm attribute analysed explained the majority of variation between the CF of milk from grass-based farms. Therefore, the study indicates that several farm practices are required to reduce $\mathrm{CF}$ of milk from grass-based farms.

Acknowledgments The authors express their gratitude to the farmers who participated in the study and thank the anonymous reviewers for their helpful comments. They also gratefully acknowledge the contributions of Andy Boland, Joe Kirk, Tim Mackey and Joe O'Toole and thank the farm auditors who carried out the on-farm surveys.

Open Access This article is distributed under the terms of the Creative Commons Attribution License which permits any use, distribution, and reproduction in any medium, provided the original author(s) and the source are credited.

\section{References}

Beukes PC, Gregorini P, Romera AJ, Levy G, Waghorn GC (2010) Improving production efficiency as a strategy to mitigate greenhouse gas emissions on pastoral dairy farms in New Zealand. Agric Ecosyst Environ 136(3-4):358-365

BSI (2011) PAS 2050:2011—specification for the assessment of life cycle greenhouse gas emissions of goods and services. British Standards Institute, London

Carbon Trust (2013) Carbon-footprinting software-footprint expert. The Carbon Trust, Dorset House, Stamford Street, London. http:// www.carbontrust.com/software

Casey JW, Holden NM (2005) The relationship between greenhouse gas emissions and the intensity of milk production in Ireland. J Environ Qual 34(2):429-436

CSO (2013) Agriculture and fishing statistical products. Central Statistics Office, Skehard Road, Cork, Ireland. Accessed December 12, 2012. http://www.cso.ie/px/pxeirestat/statire/SelectTable/Omrade0.asp? Planguage $=0$

Christie KM, Rawnsley RP, Eckard RJ (2011) A whole farm systems analysis of greenhouse gas emissions of 60 Tasmanian dairy farms. Anim Feed Sci Technol 166-167:653-662

DAFM (2011) AIM bovine statistics report 2011. Department of Agriculture, Food and Marine, NBAS Division, Backweston, Co. Kildare

Dairy Australia (2012) Summary of the final report: farming - carbon footprint of the Australian dairy industry. Dairy Australia, Southbank

DairyCo (2012) Greenhouse gas emissions on British dairy farms, DairyCo carbon footprinting study: year one. Agriculture \& Horticulture Development Board, Kenilworth

Defra (2007) The environmental, social and economic impacts associated with liquid milk consumption in the UK and its production: a review of literature and evidence. Department for Environment, Food and Rural Affairs, Nobel House, Smith square, London

Deighton M, O’Brien D, O’Loughlin B, O'Neill B, Wims C (2010) Towards reducing the methane intensity of milk production. TResearch 5(4):26-27

Duffy P, Hyde B, Hanley E, Dore C (2011a) Ireland informative inventory report 2011. Air pollutant emissions in Ireland 1990-2009 reported to the secretariat of the UN/ECE on long range transboundary air pollution. Environmental Protection Agency, Johnstown Castle Estate, Co. Wexford, Ireland

Duffy P, Hyde B, Hanley E, Dore C, O’Brien P, Cotter E, Black K (2011b) Ireland national inventory report 2011. Greenhouse gas emissions 1990-2009 reported to the United Nations framework convention on climate change. Environmental Protection Agency, Johnstown Castle Estate, Co. Wexford, Ireland

Ecoinvent (2010) Ecoinvent Centre. Ecoinvent 2.0 database. Swiss Centre for Life Cycle Inventories, Dübendorf. www.ecoinvent.ch

Evans RD, Dillon P, Shalloo L, Wallace M, Garrick DJ (2004) An economic comparison of dual-purpose and Holstein-Friesian cow breeds in a seasonal grass-based system under different milk production scenarios. Ir J Agric Food Res 43(1):1-16

Fitzgerald JJ, Mee JF, O'Grady D (2004) Systems of winter milk production based on all autumn calving cows. End of project report no. 4628. Dairy Production Department, Teagasc, Moorepark Research Centre, Fermoy, Co. Cork

Flysjö A, Cederberg C, Henriksson M, Ledgard S (2011) How does coproduct handling affect the carbon footprint of milk? Case study of milk production in New Zealand and Sweden. Int J Life Cycle Assess 16(5):420-430

Gerber P, Vellinga T, Opio C, Henderson B, Steinfeld H (2010) Greenhouse gas emissions from the dairy sector. A life cycle assessment. Food and Agricultural Organization of the United Nations: Animal Production and Health Division, Viale delle Terme di Caracalla, 00153 Rome, Italy

Hagemann M, Ndambi A, Hemme T, Latacz-Lohmann U (2012) Contribution of milk production to global greenhouse gas emissions. Environ Sci Pollut Res 19(2):390-402

Howley M, Dennehy E, Holland M, O'Gallachoir B (2011) Energy in Ireland 1990-2010. Energy policy statistical support unit. Sustainable Energy Authority of Ireland

Hyde BP, Carton OT, O'Toole P, Misselbrook TH (2003) A new inventory of ammonia emissions from Irish agriculture. Atmos Environ 37(1): $55-62$

ICBF (2012) Dairy herd plus. Irish Cattle Breeding Federation, Shinagh, Bandon, Co. Cork, Ireland. http://www.icbf.com/?page_id=149

IDF (2010) A common carbon footprint for dairy. The IDF guide to standard lifecycle assessment methodology for the dairy industry. Bulletin of the International Dairy Federation 445, $38 \mathrm{pp}$

IPCC (2006) Intergovernmental Panel on Climate Change guidelines for national greenhouse inventories. In: Eggleston HS, Buendia L, Miwa K, Ngara T, Tanabe K (eds) Agriculture, forestry and other land use, vol 4, Institute for Global Environmental Strategies (IGES). Hayama, Japan

IPCC (2007) Changes in atmospheric constituents and in radiative forcing. In: climate change 2007: the physical science basis. Contribution of working group I to the fourth assessment report of the Intergovernmental Panel on Climate Change. Solomon S, Qin D, Manning M, Chen Z, Marquis M, Averyt KB, Tignor M., Miller HL (eds). Cambridge University Press, Cambridge

IPCC (2013) Anthropogenic and natural radiative forcing. In: climate change 2013: the physical science basis. Contribution of working group I to the fifth assessment report of the Intergovernmental Panel on Climate Change. Stocker TF, Qin D, Plattner GK, Tignor M, Allen SK, Boschung J, Nauels A, Xia Y, Bex V, Midgley PM (eds). Cambridge University Press, Cambridge

Jarrige R (1989) Ruminant nutrition: recommended allowances and feed tables. John Libbey Eurotext, Montrougue

Kennedy E, O’Donovan M, Murphy JP, Delaby L, O’Mara F (2005) Effects of grass pasture and concentrate-based feeding systems for spring-calving dairy cows in early spring on performance during lactation. Grass Forage Sci 60(3):310-318

LEAP (2014) Environmental performance of animal feed supply chains: guidelines for quantification. Livestock environmental assessment and performance partnership. FAO, Rome 
Leip A, Weiss F, Wassenaar T, Perez I, Fellmann T, Loudjani P, Tubiello F, Grandgirard D, Monni S, Biala K (2010) Evaluation of the livestock's sector contribution to the EU greenhouse gas emissions (GGELS) - final report. European Commission, Joint Research Center, Ispra

Little (2002) Global comparative analysis of HFC and alternative technologies for refrigeration, air conditioning, foam, solvent, aerosol propellant, and fire protection applications, Final report to the alliance for responsible atmospheric policy. Arthur D. Little, Inc, Acorn Park, Cambridge

Lovett DK, Shalloo L, Dillon P, O'Mara FP (2008) Greenhouse gas emissions from pastoral based dairying systems: the effect of uncertainty and management change under two contrasting production systems. Livest Sci 116(1-3):260-274

Met Eireann (2013) Climate of Ireland - air temperature. http://www.met. ie/climate-ireland/surface-temperature.asp

O'Brien D, Shalloo L, Grainger C, Buckley F, Horan B, Wallace M (2010) The influence of strain of Holstein-Friesian cow and feeding system on greenhouse gas emissions from pastoral dairy farms. J Dairy Sci 93(7):3390-3402

O'Brien D, Shalloo L, Patton J, Buckley F, Grainger C, Wallace M (2012) A life cycle assessment of seasonal grass-based and confinement dairy farms. Agric Syst 107:33-46

O'Brien D, Shalloo L, Crosson P, Donnellan T, Farrelly N, Finnan J, Hanrahan K, Lalor S, Lanigan G, Thorne F, Schulte R (2014) An evaluation of the effect of greenhouse gas accounting methods on a marginal abatement cost curve for Irish agricultural greenhouse gas emissions. Environ Sci Pol 39:107-118

Olesen JE, Schelde K, Weiske A, Weisbjerg MR, Asman WAH, Djurhuus J (2006) Modelling greenhouse gas emissions from European conventional and organic dairy farms. Agric Ecosyst Environ 112(2-3): 207-220

Olmos G, Mee JF, Hanlon A, Patton J, Murphy JJ, Boyle L (2009) Peripartum health and welfare of Holstein-Friesian cows in a confinement-TMR system compared to a pasture-based system. Anim Welf 18:467-476

O’Mara F (1996) A net energy system for cattle and sheep, Department of Animal Science and Production, Faculty of Agriculture. University College Dublin, Belfield

O'Mara F (2006) Development of emission factors for the Irish cattle herd, Environmental Protection Agency. Johnstown Castle, Co, Wexford

Opio C, Gerber P, Mottet A, Falcucci A, Tempio G, MacLeod M, Vellinga T, Henderson B, Steinfeld H (2013) Greenhouse gas emissions from ruminant supply chains - a global life cycle assessment. Food and Agriculture Organization of the United Nations (FAO), Rome

Ramsbottom G, Cromie AR, Horan B, Berry DP (2012) Relationship between dairy cow genetic merit and profit on commercial spring calving dairy farms. Animal 6(7):1031-1039

Robertson LJ, Waghorn GC (2002) Dairy industry perspectives of methane emissions and production from cattle fed pasture or total mixed rations in New Zealand. Proc N Z Soc Anim Prod 62:213-218
Rotz CA, Montes F, Chianese DS (2010) The carbon footprint of dairy production systems through partial life cycle assessment. J Dairy Sci 93(3):1266-1282

Roy P, Nei D, Orikasa T, Xu Q, Okadome H, Nakamura N, Shiina T (2009) A review of life cycle assessment (LCA) on some food products. J Food Eng 90(1):1-10

SAS (2008) SAS user guide version 9.1.3. Statistical Analysis Systems Institute Inc, Cary

Schils RLM, Olesen JE, del Prado A, Soussana JF (2007) A review of farm level modelling approaches for mitigating greenhouse gas emissions from ruminant livestock systems. Livest Sci 112: 240-251

Schils RLM, Verhagen A, Aarts HFM, Šebek LBJ (2005) A farm level approach to define successful mitigation strategies for GHG emissions from ruminant livestock systems. Nutr Cycl Agroecosyst 71(2):163-175

Soussana JF, Allard V, Pilegaard K, Ambus P, Amman C, Campbell C, Ceschia E, Clifton-Brown J, Czobel S, Domingues R, Flechard C, Fuhrer J, Hensen A, Horvath L, Jones M, Kasper G, Martin C, Nagy Z, Neftel A, Raschi A, Baronti S, Rees RM, Skiba U, Stefani P, Manca G, Sutton M, Tuba Z, Valentini R (2007) Full accounting of the greenhouse gas $\left(\mathrm{CO}_{2}, \mathrm{~N}_{2} \mathrm{O}, \mathrm{CH}_{4}\right)$ budget of nine European grassland sites. Agric Ecosyst Environ 121(1-2):121-134

Soussana JF, Tallec T, Blanfort V (2010) Mitigating the greenhouse gas balance of ruminant production systems through carbon sequestration in grasslands. Animal 4(3):334-350

Teagasc (2011) Sectoral road map: dairying. www.teagasc.ie/ publications/2011/761/Roadmap_Dairy.pdf

Thoma G, Popp J, Shonnard D, Nutter D, Matlock M, Ulrich R, Kellogg W, Kim DS, Neiderman Z, Kemper N, Adom F, East C (2013) Regional analysis of greenhouse gas emissions from USA dairy farms: a cradle to farm-gate assessment of the American dairy industry circa 2008. Int Dairy J 31(Supplement 1):S29-S40

Thomassen MA, Dolman MA, van Calker KJ, de Boerd IJM (2009) Relating life cycle assessment indicators to gross value added for Dutch dairy farms. Ecol Econ 68(8-9):2278-2284

van Groenigen JW, Kuikman PJ, de Groot WJM, Velthof GL (2005) Nitrous oxide emission from urine-treated soil as influenced by urine composition and soil physical conditions. Soil Biol Biochem 37(3): $463-473$

Yan T, Agnew RE, Gordon FJ, Porter MG (2000) Prediction of methane energy output in dairy and beef cattle offered grass silage-based diets. Livest Prod Sci 64(2-3):253-263

Yan M-J, Humphreys J, Holden NM (2011) An evaluation of life cycle assessment of European milk production. J Environ Manag 92(3): 372-379

Yan MJ, Humphreys J, Holden NM (2013a) The carbon footprint of pasture-based milk production: can white clover make a difference? J Dairy Sci 96(2):857-865

Yan MJ, Humphreys J, Holden NM (2013b) Life cycle assessment of milk production from commercial dairy farms: the influence of management tactics. J Dairy Sci 96(7):4112-4124 